\title{
Spider community structure in the natural and disturbed habitats of the West Siberian northern taiga: comparison with Carabidae community
}

\section{Население напочвенных пауков (Arachnida: Aranei) естественных и антропогенно нарушенных биоџенозов северной тайги Западной Сибири и его сравнение с населением жкужелиџ (Coleoptera: Carabidae)}

\author{
I.I. Lyubechanskii \\ И.И. Аюбечанский
}

Institute of Systematics and Ecology of Animals, Frunze str., 11, Novosibirsk 630091, Russia. E-mail: lubech@rambler.ru Институт систематики и экологии животных СО РАН, ул. Фрунзе, 11, Новосибирск, 630091, Россия

KEY WORDS: spiders, Aranei, northern taiga, successions, sandpits, forest fires, Carabidae, community structure.

КЛЮЧЕВЫЕ СЛОВА: пауки, северная тайга, сукцессии, песчаные карьеры, лесные пожары, жужелицы, структура сообщества.

SUMMARY. The structure of spider community (Arachnida: Aranei) was studied in the main types of natural (forests and bogs) and anthropogenically disturbed habitats (burned places and abandoned sand pits of different age) of West Siberian north taiga (vicinity of Noyabrsk city, $63^{\circ} \mathrm{N}, 74^{\circ} \mathrm{E}$ ). Spider diversity and abundance were compared with the diversity and abundance of other epigeic predators: ground beetles $(\mathrm{Co}-$ leoptera: Carabidae).

During 4 years of investigation (1999-2002), 58 spider species from 11 families were found. Contrary to carabids, spiders were most abundant and diverse in natural ecosystems. The main factor determining the spider community organization in the North Siberian taiga is the human disturbance of ecosystems: araneocenoses were much more similar among undisturbed habitats (regardless of the development of the forest cover or hydrological regime) than among different types of disturbed habitats. The abundance of two dominating spider families (Lycosidae and Gnaphosidae) was several times lower in anthropogenically altered sites than in undisturbed habitats. The occasional component of the epigeic spider community (species inhabiting grass and forest stand) was equally abundant in natural and disturbed types of ecosystems.

Both in spider and carabid communities, the formation of the typical zonal taxocenes after disturbance occurred very slowly. However, carabid communities of intermediate successional stages are forming faster than those of spiders, and have higher biological diversity than in climax ecosystems. In climax ecosystems, the density and species richness of spiders are considerably higher than those of carabids. These patterns can be explained by different preferences of spiders and carabids toward particular types of biotopes, and by competitive interactions among two dominating groups of predatory arthropods.

РЕЗЮМЕ. В основных типах естественных (леса и болота) и антропогенно нарушенных экосистем (гари и песчаные карьеры разного возраста) западно-сибирской северной тайги (окрестности г. Ноябрьск, $63^{\circ}$ с.ш., $74^{\circ}$ в.д.) изучено население пауков (Araneae) и проведено сравнение его структуры с общими параметрами населения других наземных хищных членистоногих - жужелиц (Coleoptera: Carabidae). За 4 года (1999-2002) исследований в сборах зафиксировано 58 видов пауков из 11 семейств. Пауки, в противоположность жужелицам, более разнообразны и обильны в естественных экосистемах. Главным фактором, определяющим структуру сообщества пауков, служит антропогенное воздействие: аранеоценозы естественных экосистем более сходны между собой (вне зависимости от степени облесенности или обводненности), чем различным образом нарушенные экосистемы. В последних типичные герпетобионтные пауки двух преобладающих в северной тайге семейств (Lycosidae и Gnaphosidae) снижают свою численность в несколько раз по сравнению с естественными экосистемами. Случайный компонент аранеоценоза, включающий пауков хорто- и дендробионтов, примерно равно представлен в обоих типах экосистем. Как у пауков, так и у жужелиц формирование типичного зонального сообщества идет очень медленно, однако сообщества промежуточных стадий 
сукцессии у жужелиц формируются быстрее, чем у пауков, и имеют более высокие показатели биологического разнообразия, чем в нативных экосистемах. Ближе к терминальным стадиям сукцессии пауки резко доминируют по общей численности над жужелицами. Такая смена состава герпетобионтов может объясняться как различными биотопическими преференциями, так и конкурентными отношениями между жужелицами и пауками.

\section{Introduction}

Spiders (Arachnida: Aranei) are one of the most diverse groups of epigeic arthropods in terrestrial ecosystems of temperate climatic zone. The spider fauna of the Trans-Urals part of Russia consists of more than 1800 determined species from 38 families; the araneofauna of the Asian part of Russia is estimated as 2100 species [Marusik, 2007]. Despite of these great values, such diversity contributes only $4.7 \%$ to the world and $13.6 \%$ to the Holarctic spider diversity, where 13600 species are known [Marusik, Koponen, 2005]. The world spider fauna includes more than 40000 described species [The World Spider Catalog, 2012].

The species richness of local spider communities often varies from 50 to 150 species, which is comparable with the species richness of oribatid mites and usually higher than the number of Carabidae or Collembola species [Mordkovich et al., 2004, 2006, 2007]. Spider communities are a traditional model object in soil zoology and ecology. These arthropods, like other generalist predators (e.g. carabid beetles), are not directly dependent on the taxonomic composition of vegetation or of their potential preys, nor on the chemical features of the soil. The abundance and diversity of such animals may characterize the integral attractiveness of the habitat, its "value" [Pearce, Venier, 2006; Fereira, 2010]. On the other hand, spiders depend on the physical complexity (architecture) of their habitats more than other epigeic arthropods [Hatley, McMahon, 1980; Robinson, 1981; Halaj et al., 1998; Castro, Wise, 2010], and may have complicated competitive inter-specific interactions [Marshall, Rypstra, 1999].

Wolf spiders (Lycosidae) are especially popular in soil zoology research. Their epigeic way of life ensures the effectiveness of pitfall trapping for estimating their density and diversity. Lycosidae are not a very diverse family (not more than 40 species in the regional fauna) and may be simply distinguished to species, or at least, to "morphospecies". Noteworthy, the contribution of Lycosidae to the overall regional spider diversity varies within a narrow range of 7 to $10 \%$ [Marusik, Koponen, 2005]. It is therefore possible to estimate the overall spider diversity of the region of province scale. Another "easy to use" epigeic family of spiders are Gnaphosidae (flat-bellied spiders).

Like other Chelicerata, spiders are suitable for ecological studies because their juvenile and imaginal stages have the same life form can be sampled simultaneous- ly. Nevertheless, preimaginal stages can not be determined to species level and have to be grouped by genera or treated as "morphospecies". Another complication is that pitfall trapping works selectively and gathers only a part of the total spider community. Except epigeic species, inhabitants of grass and trees are caught, whereas the density and diversity of small-size and less mobile litter-dwelling forms, like Linyphiidae, can be underestimated.

Spiders often dominate epigeic soil fauna by their abundance and species richness, which was shown e.g. in north taiga forests of Karelia [Rybalov, Kamaev, 2011], or in high-altitude ecosystems of Siberia [S.B. Ivanov, Yu.S. Ravkin, personal communication]. Probably, spiders are weak competitors in comparison with other epigeic predators, especially carabids. This probably explains why spiders reach high abundance in places where carabids are absent. In some sense, carabid beetles are an ecological "mirror group" of spiders in oligotrophic, "slow" and unproductive northern ecosystems [Lyubechanskii, 2009]. Another cause of the abundance of spiders in high-latitude ecosystems can be their cold tolerance; some species can be active on snow cover in winter [Oliger, 2003].

The main goal of this work was to reveal the community structure of epigeic spiders in the north taiga of West Siberia, and changes in this structure caused by anthropogenic impact. Secondary goal was to compare these structural changes with those of Carabidae communities.

\section{Materials and methods}

\section{Study area and sites}

Field sampling was carried out in the vicinity of Noyabrsk city, $63^{\circ} 15^{\prime} \mathrm{N}, 74^{\circ} 30^{\prime} \mathrm{E}$, at the border of north and middle taiga of West Siberia. The studied place, Siberian Ridges (Sibirskiye Uvaly) is a large, slightly lifted (10-100 m above surrounding territories) upland formed mainly by sands and sand-clayish matrix. Siberian Ridges are surrounded by raised bogs, partly with permafrost forms of mesorelief (palsas). These bogs are sparsely covered by dwarf Scotch pine (Pinus sylvestris L.). The vegetation of the upland is more diverse: most of territory is covered by lichen woodlands dominated by larch (Larix sibirica Ledeb.) and pine with patches of birch forests in lowlands, slashes and burned places. The upland is crossed by flat valleys of small rivers belonging to the Pur river basin; forests along rivers are more diverse and include Siberian pine (Pinus sibirica Du Tour), Siberian fir (Abies sibirica Ledeb.) and spruce (Picea obovata Ledeb.). Lowland olygomesothrophic bogs are formed in numerous oxbow lakes [Smolentsev, 2002]. Anthropogenically disturbed landscapes include burned places and abandoned sand pits of different age.

Spider sampling was carried out in all types of ecosystems available in the Noyabrsk surroundings. Natural habitats were: raised permafrost palsa bog (Ta- 
ble 1, site BR), lowland bog (BL1), floodplain Siberian pine and Siberian fir forest on the banks of the YangaYakha river (FF) and primeval lichen pine forest (FP) on grey podzolic soil, undisturbed by fire and other anthropogenic stress for at least 100 years.

Several natural habitats were arranged into drainage series (catena): from lichen pine forest (FTR1) very similar to FP, through the sites of the Siberian and Scotch pine forest with different levels of soil moisture (FTR2, FTR3) to the lowland bog in the oxbow lake of the small Velkh-Pelkh-Yakha River (BL2).

The set of anthropogenically disturbed ecosystems included another catena along the slope of the sand quarry. This series begun at the same place as the series mentioned above but ran in the opposite direction. The forest on the upper (eluvial) position (G50) was burned about 50 years ago. A sparse lichen pine-birch forest with bush story composed of Juniperus sp. and Betula rotundifolia (Spach.) on sod-podzolic soil was formed at this site. Transitional positions with young birch trees, rosebay (Chamerion angustifolium L.) and turfs of woodreed (Calamagrostis epigejos L.) on sandy soil (Q5TR1, Q5TR2, Q5TR3) were consequently situated downward along the slope $\left(5-10^{\circ}\right)$ of a flattened sand pit abandoned in 1994. The bottom (accumulative) position of this catena was at the shore of a little ephemeral lake with hygrophilous vegetation (Q5AC). The length of each catena was about $300 \mathrm{~m}$, distances between adjacent positions were approximately $50 \mathrm{~m}$.

Other investigated sand quarries varied by their age of abandoning. The sand pit Q1 was abandoned in 1998, one year before sampling. This site was situated at the middle part of the slope (like Q5TR2). In quarry Q10 was overgrown with 10-15 years old pines. The quarry Q20, on loamy soil, was abandoned 20 years ago; the forest regrowth was represented mainly by birch.

Recently burned place, G10, was the patch of larchpine forest burned away by crown fire in 1992. The vegetation at this place was on the initial stage of recovering. Among burned snags, rapidly growing birches and small pines appeared. The soil was covered by dense layer of green moss with patches of woodreed and Vaccinium vitis-idaea $\mathrm{L}$.

Thus, the sites sampled formed several series of ecosystems differing by their successional stages. Postfire series included sites G10 (10 years) - G50 (50 years) - FP (more than 100 years). Sandpit series included quarry Q1 (1-4 years) - Q5TR2 (5-10 years) Q10 (10-15 years) - Q20 (20 years and more). In addition, we directly monitored changes in arthropod communities during early succession by sampling sites G10 and Q1, as well as control sites, during 4 consecutive seasons.

\section{Sampling}

Epigeic arthropods were sampled in 1999-2002 once a year. Sampling sessions lasted 10-17 days during the period of maximum spider activity (from early
July to late August). Each site was samples during at least two consecutive years. Spiders were collected using Barber's pitfall traps. The traps were made of plastic cups $6.5 \mathrm{~cm}$ in diameter and $8 \mathrm{~cm}$ deep. Ten or twenty cups were placed in each habitat studied. The number of traps and the exposition time were equal in all habitats during one season. Overall, during about 6000 trap-days more than 600 specimens of spiders were collected. Some additional data were gathered in 2002 at oil extraction sites adjoining the study area. Taxonomic status and Latin names of spiders are given according to K.G. Mikhailov's catalogue [1997] and The World Spider Catalog by N. Platnick [2012]. Statistical analysis was made using ECOS 1.3 [Azovskiy, 1993] and PAST 1.74 [Hammer et al., 2001] packages. For cluster analysis, quantitative version of Jaccard coefficient and clustering by unweighed pair group method (UPGMA) were used.

\section{Results and discussion}

\section{Spider fauna}

In total, 58 spider species from 25 genera belonging to 11 families were found in Noyabrsk surroundings. Most diverse families were Lycosidae (18 species, 5 genera), Gnaphosidae (16 sp., 5 gen.) and Linyphiidae (12 sp., 6 gen.). Other families were represented by 1-3 species from 1-2 genera (Table 1). Majority of species are widely distributed and have Transholarctic of Transpalaearctic ranges. Lycosidae and Gnaphosidae dominated by abundance, whereas Linyphiidae had considerably lower density. This can be partly explained by low mobility of these spiders. According to Marusik and Koponen [2005] method (see above), the total diversity of spiders in Noyabrsk surroundings may be estimated as 125-180 species. This confirms that north taiga ecosystems are extremely poor in comparison with neighboring forest-tundra and middle taiga zones [Lyubechanskii, 2002; Striganova, Poryadina, 2005].

Several taxa of spiders were found in 2002 beyond the main study area, in sedge grass moors and their derivatives, and oil well pads artificially made of sand and situated among these moors [Sedykh, 2005]. These habitats were situated 20-30 km north-east of Noyabrsk. Among newly found species five belonged to flatbellied spiders (Drassodes pubescens (Thorell, 1856), Gnaphosa microps Holm, 1939, Haplodrassus cf. silvestris (Blackwall, 1833), Micaria alpina L. Koch, 1872, Zelotes longipes (L. Koch, 1866)) and only one to wolf spiders: Pardosa agrestis (Westring, 1861) (?plumipes (Thorell, 1875)). We therefore can conclude that gnaphosid spiders are more hygrophilous than wolf spiders in West Siberian north taiga, and are more closely connected with grass moors than with moss bogs. In addition to species mentioned above, Xysticus cf. sabulosus (Hahn, 1832) (Thomisidae) was found in extremely warm and dry habitat of degraded pine forest near the permanently burning gas flare. 


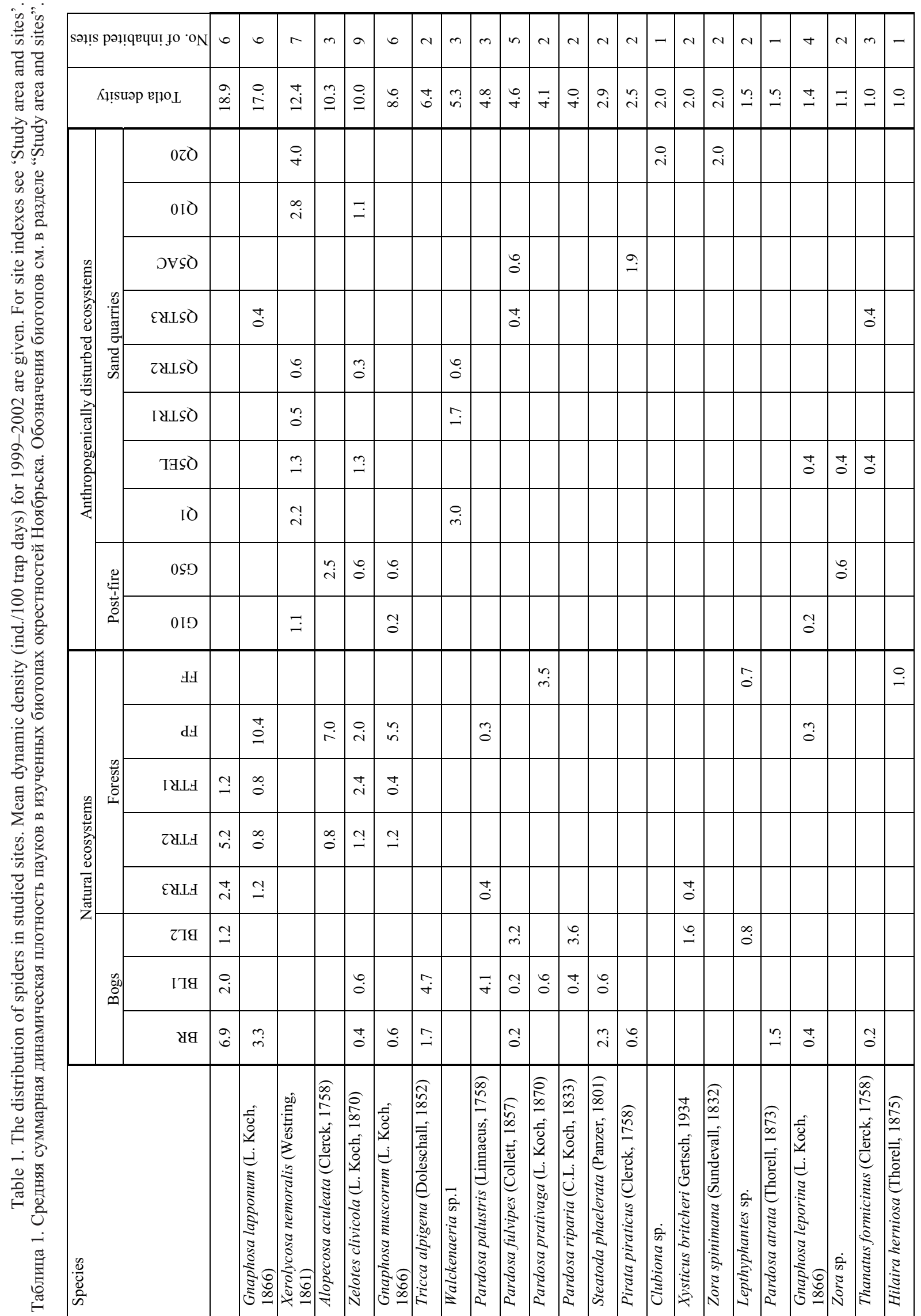




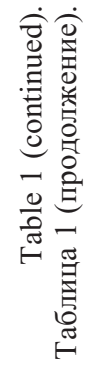

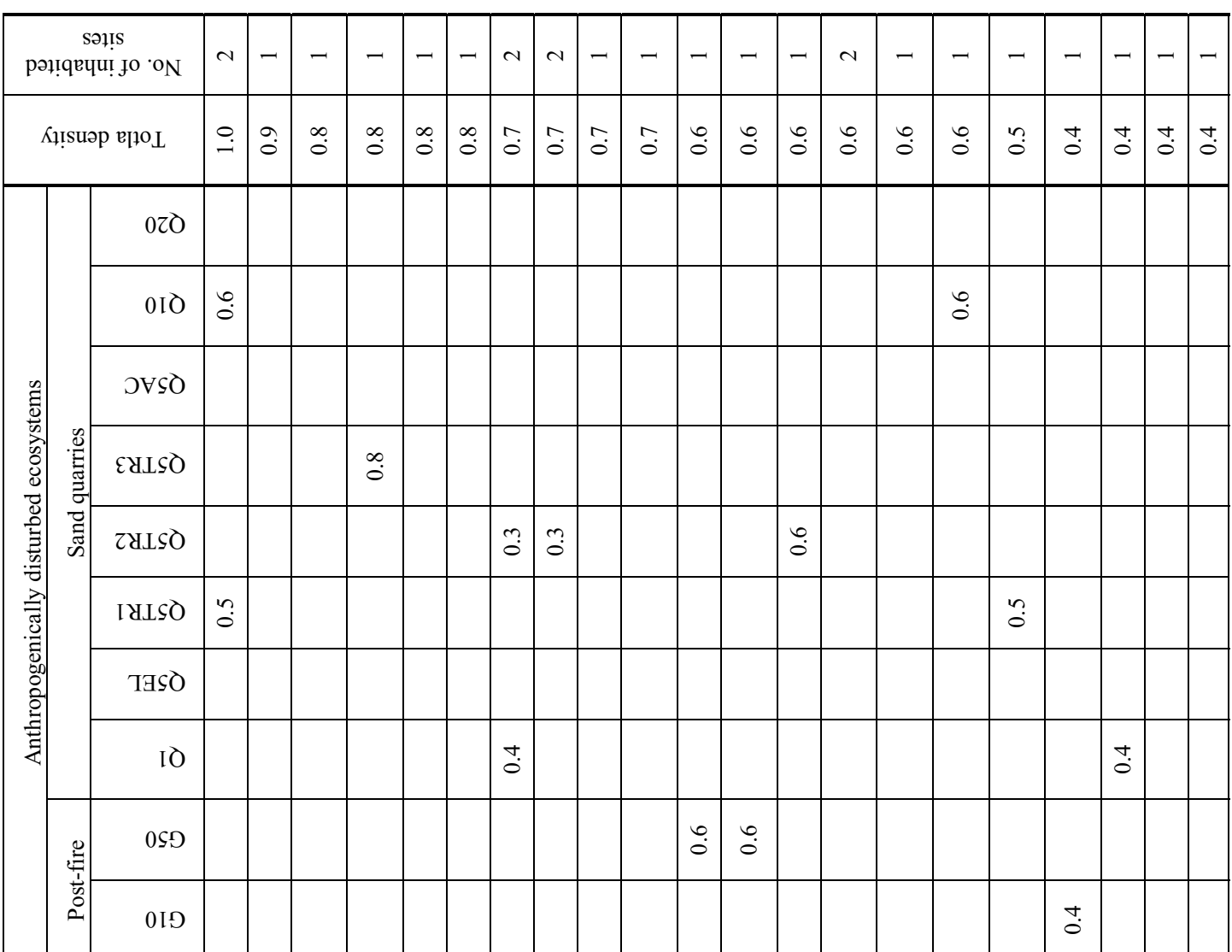

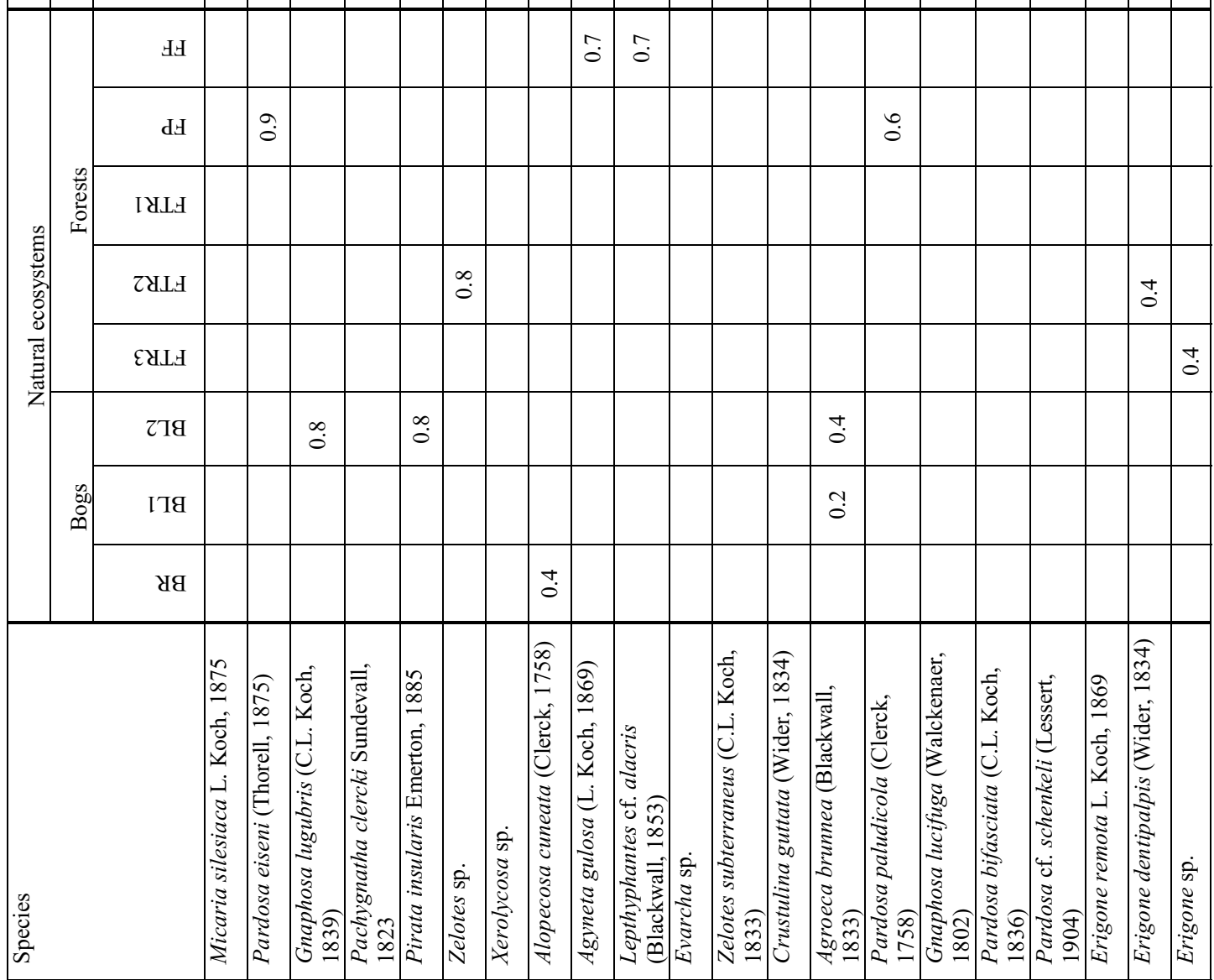




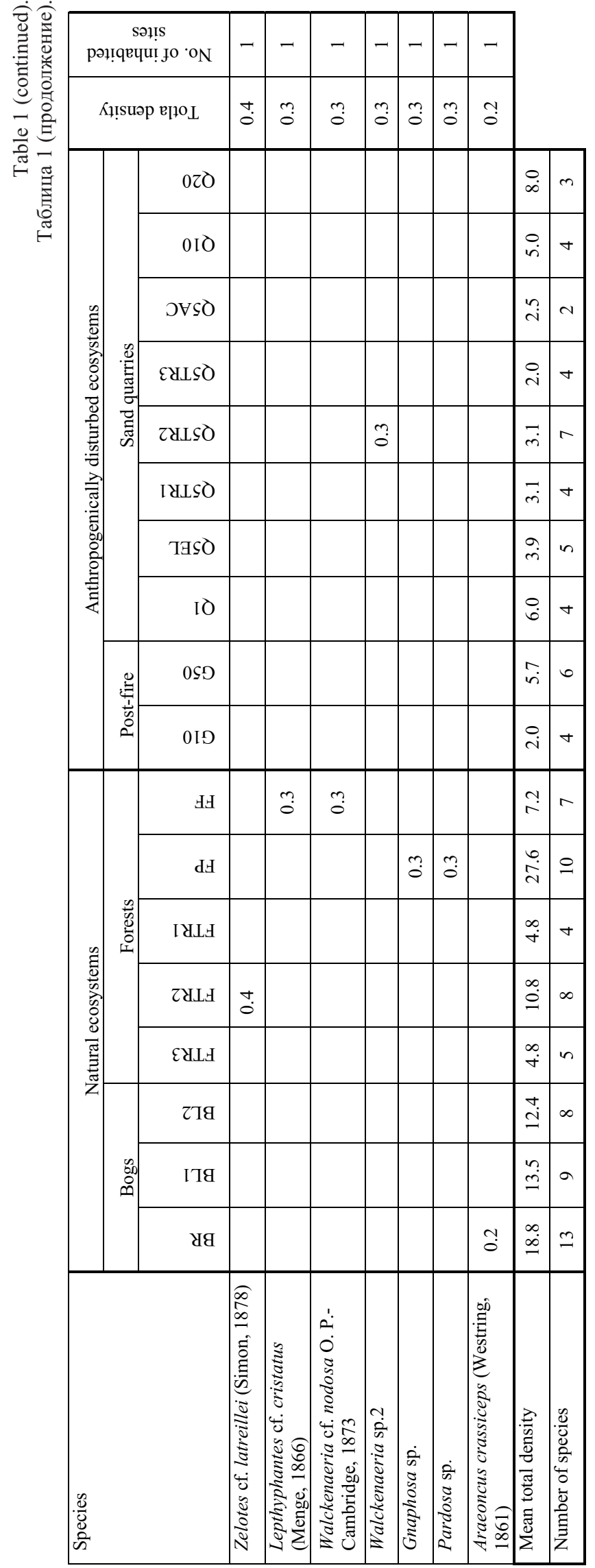

Distribution of spiders among habitats

In further analysis we used 51 spider species found at the main study sites (Table 1). The overall abundance of spiders was positively correlated with the number of habitats occupied by certain species $(\mathrm{r}=0.82, \mathrm{p}<0.05)$. However, the most abundant species did not occupy the maximum number of habitats. This suggests the presence of both eurytopic and stenotopic spiders among dominating species. The most eurytopic species, Zelotes clivicola, inhabited 9 studied sites from 18 (5 natural and 4 disturbed). Another eurytopic species, Xerolycosa nemoralis was recorded in habitats disturbed only (7 sites).

Thirty-eight spider species were recorded in natural habitats (on average $8.0 \pm 1.0$ species per site) and 22 - in antropogenically disturbed $(4.3 \pm 0.4$ species, $p=0.002)$. On the contrary, carabid beetles have higher abundance and species richness in disturbed ecosystems of north taiga [Lyubechanskii, 2002].

Different spider species predominated in natural (Pardosa saltuaria and Gnaphosa lapponum) and disturbed ecosystems (Xerolycosa nemoralis). On average, the dynamic density of spiders was slightly higher in natural habitats than in disturbed ones, but the difference was not significant $(\mathrm{p}=0.2)$. The difference becomes significant if only epigeic spiders of Lycosidae and Gnaphosidae families are taken into account.

Proportions of spider families differed in natural and changed habitats, both in number of species and in abundance. In both types of habitats wolf spiders formed about $1 / 3$ of species richness. In natural ecosystems, Lycosidae and Gnaphosidae formed almost a half of the total species richness, and only about $1 / 6$ of species belonged to other eight families. In anthropogenically changed habitats the number of species from Gnaphosidae and Linyphiidae decreased, whereas the contribution of species from less diverse families increased. The abundance of spiders of different families followed generally the same pattern. Representatives of the 8 less diverse families and Linyphiidae played main role in disturbed habitats. In natural habitats $80 \%$ of abundance was formed by wolf and flatbellied spiders.

Rank distributions of species abundance were similar in native and disturbed ecosystems. The distributions could be described with geometric and broken-stick models $(\mathrm{p}<0.0001)$. However, the "anthropogenic" distribution had shorter "tail" of rare species. This distribution could be described with logarithmic and lognormal distributions $(p<0.001)$, though this model was not applicable to the species rank distribution in natural ecosystems ( $p>0.4)$ (Fig. 1). 


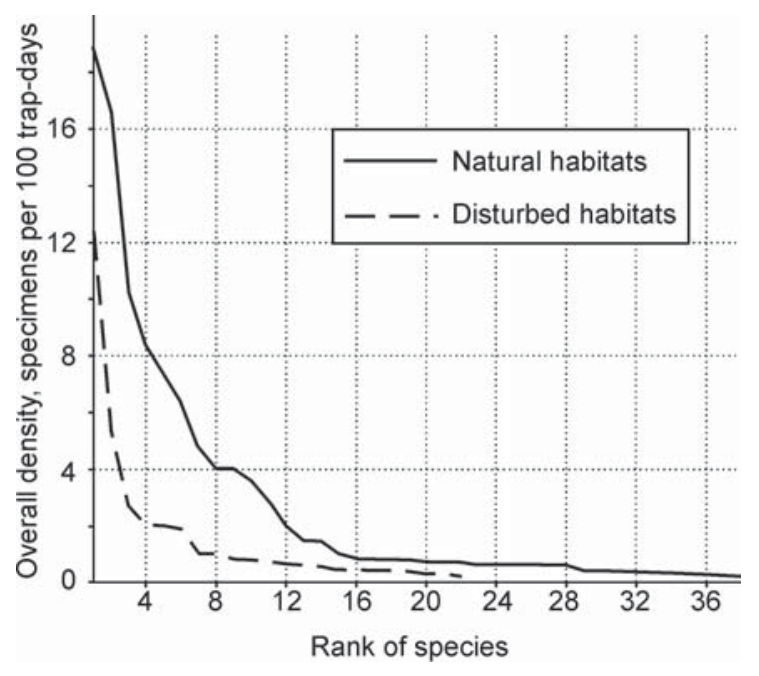

Fig. 1. Rank distributions of spider species in natural and anthropogenically disturbed habitats.

Thus, the random component including non-epigeic spider species (grass and trees inhabitants) was represented equally in natural and disturbed ecosystems. The abundance of typical epigeic spiders was several times lower in anthropogenically changed sites than in undisturbed habitats.

Cluster analysis divided studied spider populations into five main groups (Fig. 2). The most distinct site was the floodplain forest (FF), with characteristic hy-

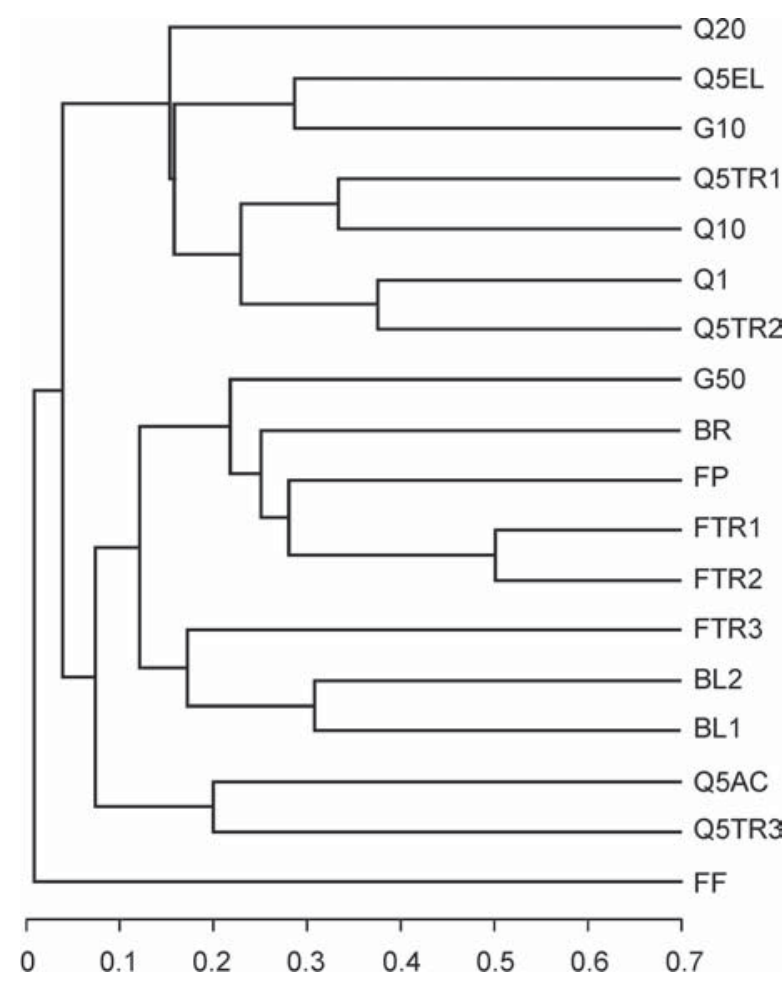

Fig. 2. Similarity of spider communities in natural and disturbed habitats. Habitat indexes see in text. grophilous species. Other sites were divided into several "anthropogenic" and "native" groups. One "Anthropogenic" set consisted of burned forest G10, and all types of quarries except overmoist ones (upper positions of Q5, Q1, Q10 and Q20). Communities of wet habitats Q5AC and Q5TR3 were relatively closer to hygrophilous community of wet natural habitats. Natural sites could be divided into lowland bogs (BL1, BL2) and wet forest FTR3, and raised bogs (BR) together with pine forests on sandy soil (FP, FTR1, G50).

We compared the "constant" part of the spider population in the same way, e.g. using for analysis only 24 species which were caught during two or more years of consecutive sampling. The same site differentiation was obtained varying only in absolute values of similarity coefficients. Thereby, anthropogenic disturbance of habitats affected the structure of spider populations much more than natural genesis of communities within xero- or hydroseries [Razumovskiy, 1981].

Succession of spider communities of the newly abandoned sand quarries

From the first to the fifth year after abandonment of the sand quarry, species richness of spiders increased from one to six species (Table 2). Overall dynamic density changed in the same way (from 6.7 to 22.8 specimens per 100 trap-days). Simultaneous sampling in a slightly older sand pit Q5TR2 (5-8 years after abandonment) revealed similar number of species with somewhat lower density (up to 8 specimens per 100 trap-days), and synchronic decrease in species richness and abundance in year 2000, probably related to hot and dry weather. Xerolycosa nemoralis, ubiquist species for the north taiga degraded ecosystems, predominated in both sites. Spider population and species composition seemingly did not stabilize during 5-8 years of initial primary succession. In contrast, carabid populations became stable already after 3-5 years after the quarry was abandoned. After this period there was no

Table 2. Changes in the species richness and dynamic density of spiders in sand quarries during early successional stages.

Таблица 2. Изменения видового богатства и динамической плотности пауков на песчаных карьерах на ранних стадиях восстановительной сукцессии.

\begin{tabular}{|l|c|c|c|c|}
\hline \multirow{2}{*}{ Quarry } & \multicolumn{4}{|c|}{ Year } \\
\cline { 2 - 5 } & 1999 & 2000 & 2001 & 2002 \\
\hline $\begin{array}{l}\text { Q1, number of } \\
\text { species }\end{array}$ & 1 & 0 & 3 & 6 \\
\hline $\begin{array}{l}\text { Q1, dynamic } \\
\text { density, ind. per } \\
100 \text { trap-days }\end{array}$ & 6.7 & 0 & 10 & 22.8 \\
\hline $\begin{array}{l}\text { Q5TR2, number } \\
\text { of species }\end{array}$ & 3 & 1 & 5 & $\begin{array}{c}\text { no } \\
\text { data }\end{array}$ \\
\hline $\begin{array}{l}\text { Q5TR2, dynamic } \\
\text { density, ind. per } \\
100 \text { trap-days }\end{array}$ & 4.3 & 0,63 & 7.8 & $\begin{array}{c}\text { no } \\
\text { data }\end{array}$ \\
\hline
\end{tabular}


Table 3. Species richness and mean dynamic density of spiders in the series of sand quarries of different age.

Таблица 3. Видовое богатство и динамическая плотность пауков в ряду песчаных карьеров разного возраста.

\begin{tabular}{|l|c|c|c|c|}
\hline Quarry & Q1 & Q5 & Q10 & Q20 \\
\hline Age, years & $\begin{array}{c}1 \\
\text { year }\end{array}$ & $\begin{array}{c}5 \\
\text { years }\end{array}$ & $\begin{array}{c}10 \\
\text { years }\end{array}$ & 20 years \\
\hline $\begin{array}{l}\text { Number of } \\
\text { species }\end{array}$ & 4 & 7 & 4 & 3 \\
\hline $\begin{array}{l}\text { Mean dynamic } \\
\text { density, ind. per } \\
100 \text { trap-days }\end{array}$ & 6.0 & 3.1 & 5.0 & 8.0 \\
\hline
\end{tabular}

difference between Q1 and Q5 in carabid community structure [Lyubechanskii, 2002].

Longer temporal consequences of quarries aged from 1 to 20 years demonstrated a moderate decrease in species diversity along with an increase in the total density of spiders (Table 3 ). This suggests that speciespoor spider communities with specific composition and low density (ca. 3 times lower than in natural pine forests) are formed in the abandoned sand quarry after 15-20 years of the primary succession. The critical stage of succession is seemingly the period when growing trees determine the type of the remediating forest (coniferous or deciduous) with corresponding features of litter layer. This stage usually takes place about approximately 10 years after the beginning of the reforestation. As in carabid communities, araneocenoses of oldest quarry are still dramatically different from the native forest communities [Lyubechanskii, 2002]. However, middle successional stages are favorable for carabids (species richness and abundance are higher than in native ecosystems) but not for spiders.

\section{Spider and carabid populations of burned sites}

In control unburned pine forest (FP) epigeic fauna was represented nearly entirely by Lycosidae and Gnaphosidae spiders (5-7 species were present every year). Spider density was at maximum in this site (47.7 specimens per 100 trap-days in year 2000). In contrast, the density of carabids was extremely low in this habitat: only 1 specimen of Carabus canaliculatus Adams, 1812 was found during 4 seasons of trapping. Such spiderto-carabid density ratio is typical for dry sparse lichen pine forests of the study area. In two similar forests [Mordkovich et al., 2006], five species of spiders were collected (4 species in each site) but carabids were absent.

In the fire-site G10 spiders appeared in significant numbers only in 2002, at the tenth year after fire. Most abundant species was Xerolycosa nemoralis (typical for disturbed habitats, especially dry quarries). The colonization of the newly burned forests by widespread and ecologically flexible spider species was reported by Moretti et al. [2004] for deciduous forests of Swiss Alps. Dominance of carabids or spiders in the fire-site
G50 changed from year by year. In total, 12 species of carabids but only 6 species of spiders were recorded. Abundant spider species were the same as in unburned forest (Gnaphosa muscorum, Alopecosa aculeata), but Gnaphosa lapponum dominating in FP was absent in G50. Spiders demonstrated the same trend as oribatid mites [Andrievskiy, Yakutin, 2012]: even after 50 years of post-fire succession spider communities only partly resembled those of zonal ecosystem.

In general, spiders preferred more structurally complex environments than carabids. In north taiga Araneae usually inhabit places with thick lichen vegetation, under the forest canopy and/or with moist soil. Carabids are more abundant and diverse in open landscapes with bare soil both in dry or moist places.

\section{Conclusion}

We can conclude that epigeic spider communities of north taiga are considerably less flexible than carabid communities, and less tolerant for such anthropogenic stresses as forest fires or soil disturbance (sand quarries). The formation of the typical zonal communities in both taxocenes is a very slow process taking more than 50 years. However, carabid communities of intermediate successional stages are forming faster than those of spiders, and have higher biological diversity than in climax ecosystems. The spider density and species richness in climax ecosystems are considerably higher than in carabid communities of the same sites. These patterns in the composition of spider and carabid communities may be explained in two ways: different preferences toward particular type of field layer vegetation, and competitive interactions between two dominating groups of predatory arthropods.

\section{ACKNOWLEDGEMENTS}

Author is very grateful to Dr. G.N. Azarkina for determination of spider species, and to Prof. V.G. Mordkovich for his help in the organization of research and for productive discussion. This work was supported by Russian Foundation for Basic Research (RFBR), grants \#\# 01-04-49533 and 04-04-49817.

\section{References}

Andrievskii V.S., Yakutin M.V. 2012. [The comparative characteristic of successions of oribatid mites (Oribatei) and soil microorganisms on sand-pits in subzone of West Siberian north taiga] // Euroasian Entomological Journal. Vol.11. No.1. [in Russian]

Azovskiy A.I., Karelin D.V. 1993. [ECOS 1.3: Program package for the analysis of ecological data. Manual]. Moscow. Moscow State university. 48 pp. [in Russian].

Castro A., Wise D.H. 2010. Influence of fallen coarse woody debris on the diversity and community structure of forest-floor spiders (Arachnida: Araneae) // Forest Ecology and Management. Vol.260. P.2088-2101

Ferreira J.G. 2010. Impact of mine pollution on the abundance and community structure of ground-dwelling spiders (Araneae): potential use as bioindicators. Universidade de Lisboa Departamento de Biologia Animal. Ph.D. Dissertation. 56 pp. 
Gravesen E. 2000. Spiders (Araneae) and other invertebrate groups as ecological indicators in wetland areas // Ekológia (Bratislava). Vol.19, Supplement 4. P.39-42.

Halaj J., Ross D.W., Moldenke A.R. 1998. Habitat structure and prey availability as predictors of the abundance and community organization of spiders in western Oregon forest canopies // Journal of Arachnology. Vol.26. No.2. P.203-220.

Hammer O., Harper D.A.T., Ryan P.D. 2001. PAST: Palaeontological statistical software package for education and data analysis // Palaeontologica Electronica Vol.4. No.1. 9 pp. http:/ folk.uio.no/ohammer/past/index.html

Hatley C.L., McMahon J.A. 1980. Spider community organization: seasonal variation and the role of vegetation architecture // Environmental Entomology. Vol.9. P.632-639.

Lyubechanskii I.I. 2002. [Carabidae beetle population of the West Siberian northern taiga and its change in the process of revegetation of sand quarries] // Sibirskiy Ekologicheskiy Zhurnal. No.6. P. 711-719 [in Russian].

Lyubechanskii I.I. 2009. Interactions between spider and carabid communities at the North Taiga of West Siberia // Carabid beetles as bioindicators. Abstracts of XIV European Carabidologist Meeting. Westerbork, the Netherlands. September 14 18. WBBS Foundation. P.37.

Marshall S.D., Rypstra A.L. 1999. Spider competition in structurally simple ecosystems. The Journal of Arachnology. Vol.27. P.343-350.

Marusik Yu.M. 2007. [Spiders (Arachnida: Aranei) of Asian part of Russia; taxonomy, fauna, zoogeography]. Autoref. of D. Sci. Thesis. Saint-Petersbourg: Saint-Petersbourg State University. 38 pp. [in Russian].

Marusik Yu. M., Koponen S. 2005. A survey of spiders (Araneae) with Holarctic distribution // Journal of Arachnology. Vol.33. No.2. P.300-305.

Máthé I., Urák I., Balog A., Balázs E. 2003. The community structure of the ground dwelling carabid beetles (Coleoptera: Carabidae) and spiders (Arachnida: Araneae) in peat bog "Mohos" (Transylvania, Romania) // Entomol. Rom. Vol.8. P.95102.

Mikhailov K.G. 1997. Catalogue of the spiders of the territories of the former Soviet Union (Arachnida, Aranei). Moscow, Zoological Museum of the Moscow State University. 416 p.

Mordkovich V.G., Andrievskii V.S., Berezina O.G., Lyubechanskii I.I., Marchenko I.I. 2004. [The animal population as an indicator of the ecological status of the soils of the North of
West Siberia under the action of pollution with oil] // Sibirskiy Ekologicheskiy Zhurnal. No.4. P.467-474 [in Russian].

Mordkovich V.G., Andrievskii V.S., Berezina O.G., Lyubechanskii I.I., Marchenko I.I. 2008. Soil Arthropoda of Post-Fire Successions in Northern Taiga of West Siberia // Contemporary Problems of Ecology. Vol.1. No.1. P. 96-103.

Mordkovich V.G., Lyubechanskii I.I., Berezina O.G. 2007. [Forest fire problem and pyrogenic successions of the communities of soil Arthropoda in Siberia] // Sibirskiy Ekologicheskiy Zhurnal. No.2. P.169-181 [in Russian].

Moretti M., Obrist M.K., Duelli P. 2004. Arthropod biodiversity after forest fires: winners and losers in the winter fire regime of the southern Alps // Ecography. Vol.27. P.173-186.

Niemela J., Haila Y., Punttila P. 2000. The importance of the small-scale heterogeneity in boreal forests: variation in diversity in forest-floor invertebrates across the succession gradient // Ecography. Vol.19. P. 352-368.

Oliger T.I. 2003. [Spiders (Aranei) active on snow in south-east Lake Ladoga region] // Euroasian Entomological Journal. Vol.2. No.4. P.251-259 [in Russian].

Pearce J.L., Venier L.A. 2006. The use of ground beetles (Coleoptera: Carabidae) and spiders (Araneae) as bioindicators of sustainable forest management: A review // Ecological Indicators. Vol.6. Issue 4. P.780-793.

Razumovskiy S.M. 1981. [Rules of the biocenotic dynamics]. Moscow: Nauka. 232 pp. [in Russian].

Robinson J.V. 1981. The effect of architectural variation in habitat on a spider community: an experimental field study // Ecology. Vol.62. P.73-80.

Rybalov L.B., Kamaev I.O. 2011. Diversity of soil mesofauna in northern taiga biogeocenoses of the Kamennaya River basin (Karelia) // Biology Bulletin. Vol.38. No.4. P. 338-347.

Sedykh V.N. 2005. [Paradoxes in the solving of ecological problems of West Siberia]. Novosibirsk. Nauka. 160 pp. [in Russian].

Smolentsev B.A. 2002. [Soil Structure in the Siberian Downs (Northern Subzone of West Siberia)]. Novosibirsk: Nauka SB RAS. 118 pp. [in Russian].

Striganova B.R., Poryadina N.M. 2005. [Soil animal population in boreal forests of West Siberian Plain]. Moscow: KMK Scientific Press Ltd. 234 pp. [in Russian].

The World Spider Catalog by Norman I. Platnick, Version 12.5. 2012. The American Museum of Natural History. http:// research.amnh.org/iz/spiders/catalog/ 